Chapman University

Chapman University Digital Commons

Film Studies (MA) Theses

Dissertations and Theses

Spring 5-2020

\title{
Smell as Self-identity: Capitalist Ideology and Olfactory Imagination in Das Parfum's Multimedia Storytelling
}

Xinrong Liu

Chapman University, 1479394408@qq.com

Follow this and additional works at: https://digitalcommons.chapman.edu/film_studies_theses

Part of the Film and Media Studies Commons

\section{Recommended Citation}

Liu, Xinrong. "Smell as Self-identity: Capitalist Ideology and Olfactory Imagination in Das Parfum's Multimedia Storytelling." Master's thesis, Chapman University, 2020. https://doi.org/10.36837/

chapman.000164

This Thesis is brought to you for free and open access by the Dissertations and Theses at Chapman University Digital Commons. It has been accepted for inclusion in Film Studies (MA) Theses by an authorized administrator of Chapman University Digital Commons. For more information, please contact laughtin@chapman.edu. 
Smell as Self-identity:

Capitalist Ideology and Olfactory Imagination in Das Parfum's Multimedia Storytelling

\author{
A Thesis by \\ Xinrong Liu \\ Chapman University \\ Orange, CA \\ Dodge College of Film and Media Arts \\ Submitted in partial fulfillment of the requirements for the degree of \\ Master of Arts in Film Studies
}

May 2020

Committee in charge:

Nam Lee, Ph.D., Chair

Erica Aguero, Ph.D.

Stephanie Takaragawa, Ph.D. 
The thesis of Xinrong Liu is approved.

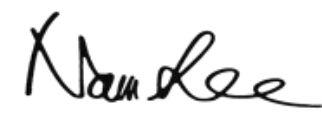

Nam Lee, Ph.D., Chair
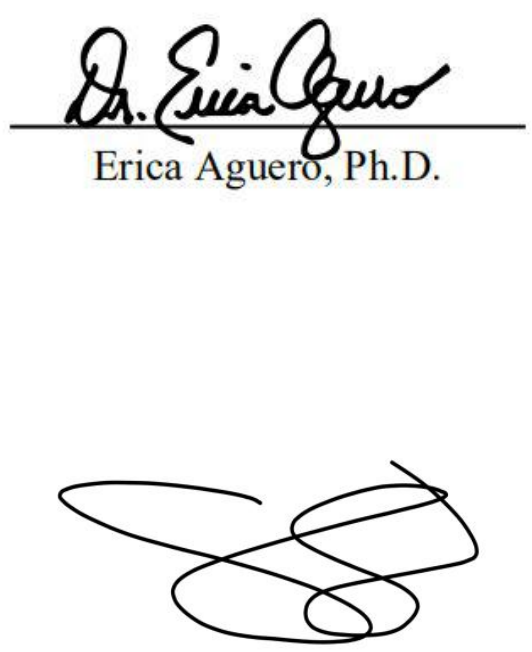

Stephanie Takaragawa, Ph.D.

April 2020 
Smell as Self-identity:

Capitalist Ideology and Olfactory Imagination in Das Parfum's Multimedia Storytelling Copyright (C) 2020

by Xinrong Liu 


\section{ACKNOWLEDGEMENTS}

I would like to express my gratitude to my faculty advisor and committee chair Dr. Nam Lee, members Dr. Erica Aguero and Dr. Stephanie Takaragawa. To Dr. Lee for her continued guidance as I completed the thesis and her enlightening instructions, care, as well as encouragements during my education at Chapman. To Professor Aguero for her support in my academic pursuit and improving my writing skills. And finally to Professor Takaragawa for her invaluable advice in conducting the initial research and completing the final thesis. From an obscure concept to a concrete product, their patience and comments are of vital importance and greatly appreciated.

I would also like to thank my family and friends for their love and understanding which enabled me to make this new adventure in film studies. I have benefited a lot from this journey while my attitude toward life has been better shaped. Finally, for all the individuals who assist me in my study at Chapman, I want to convey a special thank. Your help plays a crucial role in my life and will further encourage me to make achievements in my future career. 


\begin{abstract}
Smell as Self-identity:

Capitalist Ideology and Olfactory Imagination in Das Parfum's Multimedia Storytelling

by Xinrong Liu
\end{abstract}

This thesis explores smell as a cultural signifier in Perfume's multimedia storytelling. By establishing the theoretical ground upon the historical importance of scent, the thesis focuses particularly on its close interrelationships with the politics of identity, an issue elaborated in Patrick Süskind's novel Das Parfum-Die Geschichte Eines Mörders (Perfume: The Story of a Murderer, 1985) as well as its two screen adaptations--the film Perfume: The Story of a Murderer (dir. Tom Tykwer, 2006) and the television series Parfum (Netflix, 2018). In virtue of textual analysis and cultural studies on Theodor Adorno and Max Horkheimer's discussion on Enlightenment, Martin Heidegger's Existentialist philosophy, Foucouldian governmentality, and neoliberal language of self-sufficiency, the thesis analyzes how smell could be effectively visualized through cinematic techniques while ideologically decoding Perfume as a critique of capitalist culture that exerts manipulation, standardization, and fragmentation of individual identity. In conclusion, the three texts of Perfume provide the audience with a unique story universe about olfactory imagination to expose people's struggles with the sense of self under capitalist development. Meanwhile, the thesis proves that smell as a social and cultural discourse has crucial sense in film and media studies, whilst functioning deeply in people's everyday life. 


\section{TABLE OF CONTENTS}

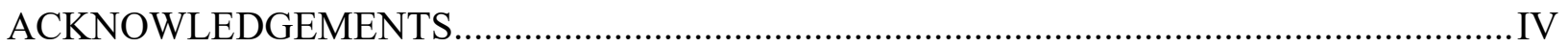

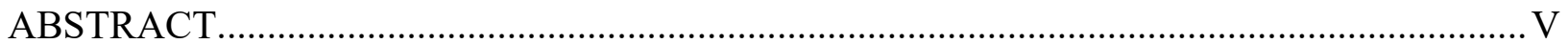

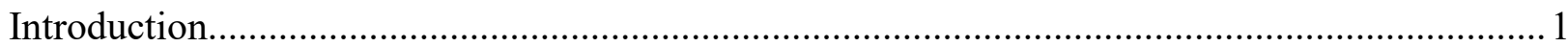

The Cultural Significance of Olfaction................................................................................ 6

Perfume: The Story of a Murderer: A Critique of Enlightenment and a Voice for

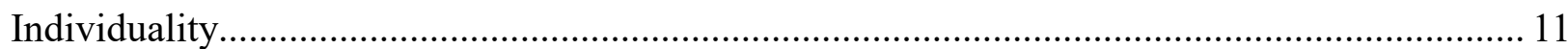

Netflix’s Parfum (2018): Fragmentation, Trauma, and Self-sufficiency

in Contemporary Neolibaral Capitalism.............................................................................. 22

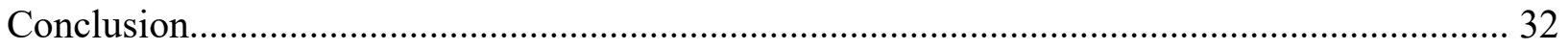

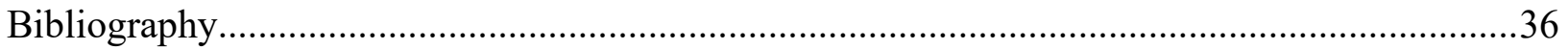




\section{Introduction}

"Smell was distinct, with every object possessing its own specific smell signature."

--Jonathan Reinarz ${ }^{1}$

Smell is invisible, fleeting, and hard to record. Depicted as "a domain that leaves no traces," ${ }^{2}$ olfactory perception is constrained by a hierarchy of sense modalities which gives the highest place to vision and the lowest equally to smell and taste. ${ }^{3}$ Thus, in the cinematic world that "ostensibly favors audio-visual senses," 4 the depiction or attention on olfaction has conceivably long been sided. Although from the 1970s, the Italian film Profumo di donna (Scent of a Woman, dir. Dino Risi, 1974) and its Hollywood remake Scent of a Woman (dir. Martin Brest, 1992) structure the sense of smell into the narrative, it is still a minor element without any cultural meanings attached. ${ }^{5}$ However, in 2006, the movie Perfume: The Story of a Murderer (dir. Tom Tykwer), an adaptation of Patrick Süskind's German novel Das Parfum-Die Geschichte Eines Mörders (Perfume: The Story of a Murderer, 1985), elaborates a story about olfactory imagination that concentrates not only on the visual and aural portrayal of scent but also on its cultural, social and historical implications.

\footnotetext{
1 Jonathan Reinarz, Past Scents: Historical Perspectives on Smell (Urbana: University of Illinois Press, 2016$), 8$.

2 Patrick Süskind, Perfume, trans. John E. Woods (New York: Vintage International,1986), 4.

3 Yanna B Popova, "“The Fool Sees with His Nose': Metaphoric Mappings in the Sense of Smell in Patrick Suskind's Perfume," Language \& Literature 12, no. 2 (2003): 138.

4 Jiaying Sim, “An Olfactory Cinema: Smelling Perfume," Acta Universitatis Sapientiae: Film and Media Studies 8 , no.1 (2014): 113 .

${ }^{5}$ Both films feature protagonists who are blind and use the sense of smell to feel the surroundings. Yet the two differ significantly as the former focuses on the character Fausto's personal affections while the latter pays more attention to social and moral problems of paranoia, injustice, and hypocrisy.
} 
In the film Perfume (2006), Jean-Baptiste Grenouille, the protagonist who identifies everything through smell yet has no scent of his own, violently murders young women for their sweet fragrance to satisfy his abnormal passion of creating a "perfect" perfume. Since everyone has his/her unique odor, scent marks a personal signature that identifies different people. By extracting women's body odors, Grenouille who lives in the eighteenth century operates a "de-scenting" of others which expresses Enlightenment culture's de-characterization in the early capitalist society. ${ }^{6}$ Argued by Theodor Adorno and Max Horkheimer that "enlightened rationality is distinguished by a tendency toward abstraction that reduces real entities to mere idealities," the age of Enlightenment is shaped by a concept of "standardization" where knowledge must be acquired through control, manipulation, and domination of the objectified world. ${ }^{7}$ While stealing others' uniqueness and transforms different women into a perfume, Grenouille wishes to use this magic perfume to make himself smelled and thus to possess a unique personal identity. This contradiction between de-characterization and uniqueness uncovers people's struggles with self-identity in the early capitalist epoch.

Based on both Süskind's novel and Tykwer's film, Parfum, a new television adaptation, launched on Netflix in 2018. Providing audiences with a new storyline of crime, mystery, and drama, the television series intensifies olfactory imagination through resetting the story in contemporary world. Whereas in the novel and the film the character Grenouille desires to find a unique identity, the television program fragments Grenouille's characteristics into a group of

\footnotetext{
${ }^{6}$ Richard T Gray, “The Dialectic of 'Enscentment': Patrick Süskind's Das Parfum as Critical History of Enlightenment Culture," Publications of the Modern Language Association of America 108, no.3 (1993): 490.

7 Gray, "The Dialectic of 'Enscentment,"” 502.
} 
characters. Embodying either Grenouille's desires or talents, the new characters use special perfumes to mediate their bodies and satisfy personal needs. In this story, smell becomes a tool of managing one's identity, a disguise that grants the dreamed things you can never obtain by being yourself. This regularization of identity testifies to Michel Foucault's concept of "governmentality" which legitimizes individuals' expanded freedom to manage themselves and their behavior. ${ }^{8}$ Based on Foucault's argument that the discourse of governmentality is closely interacted with neoliberal language of autonomy, film scholar Anna McCarthy further relates it to the notion of self-sufficiency and highlights individuals as "market-based" rational subjects to self-manage their "welfare, growth, and security" in contemporary neoliberal capitalist society. ${ }^{9}$

As McCarthy points out, self-sufficiency is usually driven by painful experience, traumatic events, and feelings of inadequacy. ${ }^{10}$ In Parfum (2008), we witness the characters endure various violence and insults that motivate them to kill and make people into perfumes. By wearing the special perfume, the characters arm themselves with multiple identities to achieve their selfish goals and correct their imperfect situations. Individual identity thus becomes a "structure"11 and a "commodity" that can be regularized and quantified, which, according to Ryan LaMothe, indicates neoliberal imagination that people are confused with "a psychotic self...preoccupied by one's own desires and fantasies." 12 By frequently referring to the novel and the film, Parfum's rewriting of the original text constructs a transmedia

\footnotetext{
${ }^{8}$ Michel Foucault, Discipline and Punish: The Birth of the Prison, trans. Alan Sheridan (New York: Vintage Books, 1995), 225.

9 Anna McCarthy, "Reality Television: A Neoliberal Theater of Suffering," Social Text 25, no.4 (2007): 25.

${ }^{10}$ McCarthy, "Reality Television," 25.

11 McCarthy, "Reality Television," 20.

12 Ryan LaMothe, “The Colonizing Realities of Neoliberal Capitalism,” Pastoral Psychology 65, no.1 (2016): 30.
} 
storytelling which, according to Henry Jenkins, produces a "unified and coordinated entertainment experience across platforms."13 In this sense, Perfume's three texts intensify and diversify a critique on capitalist development from a unique perspective of olfactory perception.

This thesis addresses Süskind's novel and its two screen adaptations--the film Perfume: The Story of a Murderer as well as Netflix's television series Parfum--as a critique of capitalist culture that exerts standardization and fragmentation of personal identity through olfactory imaginations. Firstly exploring the overall historical and social importance of scent as well as its connection to the issue of identity, the thesis revalues smell as a significant cultural discourse relating to capitalist ideology. Then, by examining the novel and the 2006 film which tell the same story about the character Grenouille, it discusses the ways the film uses cinematic techniques, including tracking shots, accelerated editing, dream sequence, close-ups, and non-diegetic sound effects, to successfully visualize smell and to elaborate the aesthetic and cultural aims of the novel. Although the book has mostly been interpreted as a text reflecting Enlightenment's repression on individual identity, few have paid attention to Grenouille's ultimate reaction of suicide to this effect. As something which "cannot be taken away from a particular individual,"14 death implies a fight for uniqueness that truly belongs to oneself. Thus,

\footnotetext{
${ }^{13}$ Henry Jenkins, "The revenge of the origami unicorn: Seven principles of transmedia storytelling (well, two actually, five more on friday)," Confessions of an ACA Fan (blog), The Official Weblog of Henry Jenkins, December 12, 2009, http://henryJenkins.org/2009/12/the revenge of the origamLuni.html. This TV series can be discussed in terms of "transmedia storytelling" but that it is beyond the scope of this thesis which is mainly focused on the olfactory imagination and its cultural meaning.

${ }^{14}$ Havi Carel. Life and Death in Freud and Heidegger (Amsterdam: Brill Academic Publishers, 2006), 72.
} 
Grenouille's death expresses an important existentialist thought of "being an individual"15 under Enlightenment's ideological system.

While the film proclaims Enlightenment's repression and Grenouille's fighting for a unique identity, the television series Parfum (2018) shifts the attention from Enlightenment logic of early capitalism to the fragmented atmosphere of the present day by creating new stories that reflects contemporary neoliberal capitalism. By adopting a non-linear narrative structure and unique character design, Parfum (2018) divides Grenouille into a group of characters embodying different part of his personal traits to expose the social imaginary of fragmentation under neoliberal capitalist context. In addition, such character design further legitimizes the language of suffering, self-sufficiency, and commodification, thereby reinterpreting the notion of smell to signify new implications regarding the issues of identity and gender. Expanding the narrative into a transmedia storytelling, the television program significantly widens our comprehension of Perfume's story universe. Thus, by analyzing the three texts, the thesis elaborates how the notion of smell expresses suppression, fragmentation, and self-management of identity under capitalist ideology. Meanwhile, as a magic and fantastical imagination in Perfume, smell demonstrates its close relationship with our everyday life.

15 Thomas R Flynn, Existentialism: A Very Short Introduction (Oxford: Oxford University Press, 2006), 24. 


\section{The Cultural Significance of Olfaction}

It is from the sense of smell, rather than from the other senses, that we gain the fullest picture of the great dream of disinfection and of the new intolerances, of the implacable return of excrement, the cesspool epic, the sacralization of woman, the system of vegetable symbols. --Alain Corbin ${ }^{16}$

In the early to mid-1980s, a "watershed moment for smell" came into public awareness with the rise of two key publications: Alain Corbin's Le miasme et la jonquille (The Foul and the Fragment: Odor and the French Social Imagination, 1982) and Patrick Süskind's Das Parfum (Perfume: The Story of a Murderer, 1985). ${ }^{17}$ While the former progressed scholarly research on scent from very broad perspectives of science, medicine, urban studies, public health, and psychohistory, ${ }^{18}$ the latter expanded scent's influences into the realm of popular imagination and unmasked its profound implications regarding the politics of identity. These two works subverted the previously held perception that smell is a primitive and instinctual sense without cultural, social, and historical meanings.

In his article "The verbs of perception: a typological study", Åke Viberg states that there is a hierarchy of sense modalities that vision enjoys the highest place while smell and taste remain equal in the lowest. ${ }^{19}$ Similarly, Jonathan Reinarz states that "the sense of smell remains

\footnotetext{
16 Alain Corbin, The Foul and the Fragrant : Odor and the French Social Imagination (Cambridge: Harvard University Press, 1986), 231-232.

17 Reinarz, Past Scents, 2-3.

18 Corbin, The Foul and the Fragrant, 5.

19 Åke Viberg, “The Verbs of Perception: A Typological Study," Linguistics: An Interdisciplinary Journal of the Language Sciences 21, no.1 (1983): 136.
} 
at the bottom of the sense hierarchy, where it has lingered for centuries." 20 Since ancient thinkers such as Plato and Aristotle set the tone of relegating smell to the slightest important position in the sensory, language, and cultural system, the studies on smell has been relatively lacking in the historical map. Plato contends that smell was "not delicate enough" and lacked any definite pattern, which makes it unstable and hard to perceive. ${ }^{21}$ To Aristotle, smells had no developed language to depict itself, thereby "forcing those who tried to describe them to turn to emotional classification." 22 From the first to the eighteenth century, only pieces of discussions existed about scent's relations to human body, soul, and disease, etc. For instance, Christian intellectuals provided admirable notes that "scents could incite divine wrath as well as condemnation from the wider religious community," 23 which explains its involvements with the daily practices of Church. Then, throughout the Middle Ages, olfactory perception was closely interrelated with other senses, while scholars such as Bartholomew studied scents in relation to brain, nerve, and intelligence. ${ }^{24}$ When entering the era of Renaissance, Reformation, and Enlightenment, scent was denigrated as distraction and "false witness" to the truth, ${ }^{25}$ an understanding established and maintained up to the eighteenth century.

Up until the nineteenth century, organized studies of olfaction began to form. Firstly, American physician Oliver Wendell Holmes realized olfaction's power in reaching people with memory, imagination, and other psychological impressions, while literary works that paid

${ }^{20}$ Reinarz, Past Scents, 5.

${ }^{21}$ Reinarz, Past Scents, 5-8.

22 Reinarz, Past Scents, 5-8.

${ }^{23}$ Reinarz, Past Scents, 10.

24 Reinarz, Past Scents, 11

${ }^{25}$ Annick Le Guérer, Scent, the Mysterious and Essential Powers of Smell (New York: Random House Kodansha USA Inc, 1993), 161. 
attention to the sense of smell began to appear. ${ }^{26}$ Writers, such as Charles Baudelaire, Emile

Zola, and Charles Dickens, depicted the ties among scents, woman, and places in their poems or

fictions. ${ }^{27}$ Within this context, Hippolyte Cloquet offered the first systematic study of the physiology and psychology of the olfactory system. ${ }^{28}$ Moreover, with the rise of public health movements and disease research, the odor of air and body received more attention and further stimulated the related studies on the varied functions of smell. For example, Darwin explored the role of olfaction in sexual life; Freud studied the repression of smell in the process of civilization; and George Orwell examined the way odor manipulated social hierarchies in the West. $^{29}$

During the 1980s, Alain Corbin in The Foul and the Fragment articulated the profound influence of odors over people's lives in French society during the eighteenth and nineteenth

26 Reinarz, Past Scents, 6.

27 Reinarz, Past Scents, 6-7. See Baudelaire's poems "The Flowers of Evil"-- La Cheveleure's depiction on the smell of a woman's hair: “...O odorous wood!/ My soul, as other souls put forth on the deep flood/ Of music, sails away upon they scent instead." See Zola's Nana, the depiction of Count Muffat's first visit to see Nana at a theater with "haunting" smells: "... the reek of gas, of the glue used in the manufacture of the scenery, of dirty dark nooks and corners, of the questionably clean chorus-girls...an odour of womankind--a musky scent of oil and essences mingling with the natural pungency exhaled from human tresses." See Dickens" "Hard Times," the portrayal of Coketown: “...There was a stifling smell of hot oil everywhere. The steam-engines shone with it, the dresses of the Hands were soiled with it, the mills throughout their many storeys oozed and trickled it. The atmosphere of those Fairy Palaces was like the breath of the simoon..."

28 Stephen Kern, “Olfactory Ontology and Scented Harmonies: On the History of Smell,” Journal of Popular Culture, no.7 (1974): 816. Hippolyte Cloquet's “Osphresiologie, Ou Traite Des Odeurs, Du Sens et Des Organes de l'olfaction" was first published in 1821. Now situated in the collection of Austrian National Library, there exist only French version with occasional imperfections such as missing or blurred pages, poor pictures, errant marks, etc. The book studies olfactory perception from the perspectives of Medical / Otorhinolaryngology and Medical / Physiology.

${ }^{29}$ Kern, “Olfactory Ontology and Scented Harmonies," 817. See Darwin's The Descent of Man, olfactory system's effects in sexual selection; Freud's Civilization and its discontents, the decline of the sense of smell as a feature of modern civilization; George Orwell's The Road to Wigan Pier:odor as a manipulation of social hierarchies in the West by summing up " 'four frightful' words...the lower classes smell." 
centuries, which was finally "putting smell on the historical map." ${ }^{30}$ In this book, he contends that smell-related movements, such as public health, constituted significant components of the social, political, and cultural changes in France, while the attention on the relationships between smell, science and humanities started to penetrate into people's everyday life. Furthermore, Patrick Süskind's international best seller Das Parfum reinforced the interests of both scholars and the public in olfactory perception. Depicting a maniacal genius who kills twenty-five young women for their body scents to make a "perfect" perfume, the novel adopts a fantastic narrative to signify deeper socio-political discourses regarding smell and identity.

In his book, Past Scents, Jonathan Reinarz explores the intimate connection between odor and the notions of identity, which presumes two levels of awareness: group and individual identity. ${ }^{31}$ In regard to the collective identity, Reinarz argues that "each community or commodity possesses its own peculiar scent," 32 yet such distinctiveness can meanwhile function as a limit dividing different groups, especially that of human odors. Constantly classified by "sex, race, age, diet, and even hair color," people are shaped in a moral system "where the good smelled pleasant and their opposites reeked." 33 Under this premise, smell violently sets borders and marks "the other" with "different and unpleasant scents" 34 to implant prejudice. For example, developing countries are described as the foul; the smell of Indian food frequently causes olfactory fear; migrant group was seen as undesirable or even a burden on British society

30 Corbin, The Foul and the Fragrant, 5.

31 Reinarz, Past Scents, 18.

32 Reinarz, Past Scents, 20.

33 Reinarz, Past Scents, 18-19.

34 Reinarz, Past Scents, 21. 
because of their body odor. ${ }^{35}$ Thus, the group identity expressed by smell contains profound cultural meanings in the advancement of human history.

The other important category of identity that connects closely to olfaction is individual identity. Here our discussion becomes more specific with the development of perfume. From ancient times, men and women have selected particular scents to perfume themselves, which indicates perfume's role of distinguishing different people. ${ }^{36}$ According to historian Richard Stamelman, perfume "speaks the body,"37 explaining that "a choice of fragrance has permitted wearers to modify that individual signature." ${ }^{\prime 3}$ This claim suggests a notion of individual identity which everyone is distinguished for their unique body scents, whether natural or artificial. Reinarz's work summarizes a lot of important aspects on the associations between smell and identity, and such a close correlation is manifested in Süskind's Das Parfum and its two screen adaptations. The three texts intensively inform smell's crucial role in addressing the issues of identity.

${ }^{35}$ Reinarz, Past Scents, 90-98.

${ }^{36}$ Reinarz, Past Scents, 98.

${ }^{37}$ Richard Stamelman, Perfume : Joy, Obsession, Scandal, Sin ; a Cultural History of Fragrance from 1750 to the Present (New York: Rizzoli, 2006), 18.

${ }^{38}$ Reinarz, Past Scents, 113. 
Perfume: The Story of a Murderer: A Critique of Enlightenment and a Voice for

\begin{abstract}
Individuality
The soul of being is their scent.

--Grenouille in the film Perfume: The Story of a Murderer ${ }^{39}$

For after all, he (Grenouille) was masked with the best perfume in the world, and

beneath his mask there was no face, but only his total odorlessness.
\end{abstract}

--Patrick Süskind ${ }^{40}$

In the novel and the film Perfume, Grenouille stays in a scentless cave on the mountain "Plomb du Cantal" ${ }^{41}$ for seven years, enjoying himself without distractions from human society. Yet one day, a frightening dream occurs featuring the first girl he has killed: he follows the girl who sells yellow plums in the streets of Paris, immersing himself in her pleasant body odor. Yet when she turns around and faces him directly, her eyes linger around with a blank expression, as if Grenouille, the man standing right in front of her, does not exist. This dream triggers a great terror, which suddenly wakes Grenouille up with a realization that he has no specific scent of his own. For a person who identifies everything with smell, this fact of lacking personal scent means an absence of identity--if he cannot smell himself, he cannot identify himself, thereby he will never know who he really is. This plot vividly presents the connection between smell and

\footnotetext{
39 Perfume: The Story of a Murderer, directed by Tom Tykwer (2006; Germany: Constantin Film; France: Metropolitan Filmexport), DVD, 147 min.

40 Süskind, Perfume, 145.

${ }^{41}$ Süskind, Perfume, 73.
} 
identity, which signifies profound cultural implications on Enlightenment's repression effects and Existentialist thoughts of "being an individual." 42

Süskind's novel and Tykwer's film tell the same story, offering a narrative combining biography, crimes, and fantasy about olfactory perception. The story depicts a genius who grasps the world exclusively through smell: Jean-Baptiste Grenouille. From his birth, he has an extraordinary acute sense of smell and can identify all the scents around the world--an uncommon ability that makes people around unnerved. Having his childhood drifted between orphanage and tannery, he survives all the hardships, waiting for an opportunity to expand his knowledge of smell. One day in Paris, he walks on the street and is attracted by an "exquisite"43 scent, which is from the body of a young girl who sells yellow plums. This encounter stimulates his ambition that he must learn to preserve such beautiful scents and possess them forever. Thus, he learns different methods of capturing smell, and in this process realizes a scary fact that he has "no scent of his own." 44 Fearing this "odorlessness" 45 would lead him to be a "nobody," he kills young women for their appealing fragrances to make a "best" 46 perfume, believing that it will make himself smelled and thus prove his existence. When arrested for committing several murders, he applies drops of that best perfume on his body and successfully transforms his own execution into a large orgy. At that moment, he realizes that all of the worship, admiration, and reverence are only illusions created by the perfume, which could not turn him into a "person"

\footnotetext{
42 Flynn, Existentialism, 24.

43 Süskind, Perfume, 27.

44 Popova, "“The Fool Sees with His Nose,"” 136.

45 Süskind, Perfume, 145.

46 Süskind, Perfume, 145.
} 
and grant him a unique identity. With his dream perished, he pours the rest of the perfume over himself and is devoured by a group of tramps who believes they act out of love.

As a literary work paying attention to the sense of smell, how to make such an invisible and fleeting phenomenon fully conveyed and appreciated by the readers draws our concern. Aristotle once claimed that "the language of smell has always been underdeveloped," 47 while linguist Eve Sweetser suggests that "vision is our primary source of objective data about the world...identical for different people who can take the same point of view." ${ }^{\prime 48}$ While the protagonist Grenouille perceives the whole world through smell rather than sight, his world of scent is supposed to be an alienated realm that most people cannot understand. However, his unique olfactory universe is vividly presented by using "visual metaphors," which means, Süskind refers to "our language" to portray an unfamiliar world of Grenouille's: his "process of smelling" is illustrated "very much like the process of seeing for us." 49

For Grenouille, nose equals to eyes, which enables him to see not only the face of the earth but also the hidden details. For example,

“... It was a mixture of human and animal smells, of water and stone and ashes and leather, of soap and fresh-baked bread and eggs boiled in vinegar, of noodles and smoothly polished brass, of sage and ale and tears, of grease and soggy straw and dry straw...And he (Grenouille) did not merely smell the mixture of odors in

\footnotetext{
47 Reinarz, Past Scents, 5.

48 Eve Sweetser, From Etymology to Pragmatics : Metaphorical and Cultural Aspects of Semantic Structure (Cambridge: Cambridge University Press, 1991), 38.

49 Popova, "“The Fool Sees with His Nose," 141.
} 
the aggregate, but he dissected it analytically into its smallest and most remote parts and pieces." ${ }^{50}$

Similarly, when he arrives at Grasse to learn new method of preserving smells, "he closed his eyes and concentrated on the odors that came floating to him from the building across the way. There were the odors of the kegs, vinegar and wine...then the odors of wealth that the walls exuded like a fine golden sweet...The scents of the garden descended upon him, their contours as precise and clear the colored bands of a rainbow." ${ }^{n 1}$

These words, which can be imagined and witnessed by the readers, provide a possibility to visualize the literary text into images. Most of the nouns and verbs depicting Grenouille's universe of scent in the novel testifies to the domain of vision in the mass' understanding of the world. Therefore, when the "visual vocabulary" 52 in the novel is transformed onto the screen in 2006, audience are not only able to "smell" what Grenouille smells but also to comprehend the profound cultural meanings underlying in the written text through visual-audio perception. Basically retaining the novel's main plots and the central ideas, the film Perfume: The Story of a Murderer applies unique cinematic techniques--tracking shots, accelerated editing, dream sequence, close-ups, and non-diegetic sound effects--to visualize different scents.

The most distinctive and delicate visual design in the film is tracking shot, which is mostly used to portray the fleeting scents and Grenouille's extraordinary olfactory capacity. In

\footnotetext{
50 Süskind, Perfume, 23.

51 Süskind, Perfume, 100.

52 Popova, "“The Fool Sees with His Nose,"” 144.
} 
the beginning of the movie, a long tracking shot with a voice-over vividly brings "Paris of stench" in the novel to life. In the beginning, the camera lingers in a foul fish market, tracking people who wear dirty clothes, horses hauling goods, and numerous disgusting fish stands, which finally stops at a pregnant woman who is gutting fishes. After a quick birth, she throws the baby aside and goes back to work, while the camera gradually moves closely to the baby, Grenouille. Following by a series of quick cuttings on the smelled objects around--fishes, dogs, rats, and trashes-baby Grenouille suddenly starts to cry as if he is annoyed by the stink. Upon implying his olfactory talents, this sequence successfully makes the audience feel the "smell" and the stench in the film when the camera is tracking different things. Since scents are always fleeting, fluid, and unfixed, using tracking shots proves to be a wise and effective strategy to pursue, capture, and visualize smell. The tracking shot widely functions within the entire film, appearing in the scenes that depict different odors and Grenouille's acute sense of smell.

While the tracking shot operates well in visualizing the invisible scents, it is not working alone but accompanied with close-ups, slow motion, and accelerated editing techniques, so that the glamour of scents is further made visible in front of the audience. For instance, when Grenouille firstly steps his feet on Saint-Jacques-de-la-Boucherie and Saint-Eustache of Paris, ${ }^{53}$ he greedily smells the varied odors in that "wonderland"--those of people's, commodities', and perfumes', etc. In this scene, the tracking shot of different objects is combined with the close-ups of Grenouille's face and his light twitch of nose, constituting a subjective camera of his smelling action. While he is sensing various odors, the camera zooms in on the

53 Süskind, Perfume, 23. 
corresponding objects, as if we are following his olfactory trajectory to feel the world in the movie. Thus, Grenouille's unique world of smell is better identified to the audience through the visual portraits. Similarly, combining tracking shot with slow motion also amplifies the effects of scents. When Grenouille senses the beautiful odors from the girl selling yellow plums, his gesture of smell is composed with a slow motion sequence of the girl. One the one hand, the slow motion holds on the moment, floating the appealing odor for a longer time for the audience to feel; on the other hand, it forms a contrast to Grenouille's fast running and seeking, which highlights the importance of this encounter as it is a crucial turning point in his life--he must learn to keep smells. In these scenes, accelerated editing is also applied to elicit intensified feelings on Grenouille's talent of smell. Likewise, in a scene that portrays his first meeting with the perfume-maker Baldini, he decomposes the perfume "Amor and Psyche," a best-seller in Paris at the moment created by another perfume-maker, and refines it in his own term. The camera tracks Grenouille's actions with accelerated cuttings between his picking, mixing, and shaking of different oils, which creates a feeling of tension and makes the audience concentrate on Grenouille's operations. This also enhance our understanding of his unique ability of discerning different smells.

Another important strategy of visualizing smell is dream sequence, usually portraying fragrances with non-diegetic music attended. To illustrate, when Baldini opens the perfume that Grenouille refines based on "Amor and Psyche," which is added with more floral oils, a dream sequence happens where he situates himself in a beautiful garden filled with flowers and herbs of pleasant odors. At the very moment, a charming woman comes to his ear and says "I love 
you." With an elegant melody accompanied, this dream plot vividly presents the glamour and magic effects of perfume. In addition, dream sequence appears several times in Grenouille's self-realization and search for personal identity, which inspires intense emotions and reactions in his grasp of the world and his own existence. As previously indicated, it is a dream about the girl who sells yellow plums that makes him aware of his "odorlessness," while also an imagination about her breaks his dream of possessing a personal identity. Hence, the various cinematic techniques, especially dream sequence, become a crucial medium in expressing the novel and the film's aesthetic, thematic, and cultural concerns, legitimizing a critique on Enlightenment culture's repression on personal identity and a voice for individuality.

In Perfume, Grenouille's "odorlessness" and his talent and stress on the sense of smell induce a struggle of self-identity in his grasp of the world. While the lacking of personal odor drives him to seek personal uniqueness, his acute sense of smell is utilized to deprive others' scents and characteristics. Revolving around these two premises, the novel and the film form three frames to criticize Enlightenment's repression on modern ego and express Grenouille's struggle for individuality--his valuing of smell, his robbing of others' scents for his own uniqueness, and finally his suicide.

Grenouille's talents and reliance on smell, on the one hand, states his distinctiveness as he adopts an entirely different perspective from others to comprehend the world. While most people do not depend on smell to perceive the surroundings, Grenouille does not follow the trend yet persist on his own way of cognition. Using his nose to explore the world deviates from the common views that most people adopt, which presents his uniqueness and makes him a 
person who dares to stand for his own belief. On the other hand, his valuing of smell directly attacks Enlightenment's dialectic of control, domination, and suppression on modern ego. The story of Perfume sets in the eighteenth-century Paris, which, according to Jonathan Woolley, resonates in particular with Alain Corbin's investigation on the "relation between smell and the French social imagination during the Enlightenment." 54 In this period, smell, as a "disgrace" and "distracting sensuality," was suppressed to the largest extent in order to keep human being civilized. ${ }^{55}$ In Perfume, people in French were enthusiastic to use popular artificial perfumes to suppress their natural odors, which vividly depicts Enlightenment's "disciplines of social control" ${ }^{\prime 2}$ : as people are covered with similar scents, their uniqueness is erased and thus individual personalities are lost. Situated in such a historical context where smell ought to be dominated and controlled, Grenouille's valuing of olfaction declares a critique on Enlightenment's "repression of the natural in man" 57 for he does neither want to violently suppress the natural human odors nor to be smelled like someone else with the popular perfumes sold in the market. However, as a person who owns no odor of himself but identifying everything through the sense of smell, unable to be smelled means he cannot be identified. This lacking of personal odor forces him to apply special perfumes to make up his body which leads us to understand why he distills other people's scents to satisfy his personal aim.

\footnotetext{
54 Jonathan Woolley, "Home Truths: The Importance of the Uncanny for Patrick Süskind's Critique of the Enlightenment in Das Parfum," German life and letters 60, no.2 (2007): 230.

55 Max Horkheimer and Theodor W Adorno, Dialectic of Enlightenment, trans. John Cumming (New York: Continuum,1994), 185.

56 Corbin, The Foul and the Fragrant, 6.

57 John Grumley, “The Dialectic of Enlightenment Reconsidered," Critical Horizons 20, no.1 (2019): 73.
} 
Grenouille's robbing of others' scents reveals both Enlightenment ideology of "standardization" 58 and a voice of "being an individual." 59 According to Adorno and Horkheimer, Enlightenment thoughts of standardization is a process of eliminating uniqueness by "reducing individuals to mere placeholders in an artificially inducible, infinitely iterable formal structure." ${ }^{00}$ In Perfume, by killing different young women and transforms them into components of the "perfect" perfume, Grenouille wipes their individual characteristics and turns them into a formula, appearing in the same form in a bottle with no name and no difference from each other. Through this manipulation of smell, Grenouille violently exerts the language of de-personalization to transform the particular to general. ${ }^{61}$ And by applying this perfect perfume to his own body, he hopes to be smelled and thus to possess a personal identity. Thus, Grenouille's pursuit of a unique identity becomes a process of domination and repression on modern ego, which criticizes Enlightenment's "language of control" and de-characterization. ${ }^{62}$ His demand of "being an individual" 63 and the method of negating others' distinctiveness vividly legitimizes people's struggles with identity under the logic of Enlightenment culture.

When Grenouille finally completes his perfect perfume which has unparalleled power of enslaving the world, he applies drops of it on his body in the execution and makes people totally lose themselves in the pleasant fragrance. Worshiped as an angel and even God, the perfume indeed makes Grenouille feel triumphant for a moment, as if he is not only smelled, but also

${ }^{58}$ Gray, "The Dialectic of 'Enscentment," 492.

59 Flynn, Existentialism, 24.

${ }^{60}$ Gray, "The Dialectic of 'Enscentment,", 492.

${ }^{61}$ Grumley, "The Dialectic of Enlightenment Reconsidered," 73.

${ }^{62}$ Gray, "The Dialectic of 'Enscentment,"” 492.

${ }^{63}$ Flynn, Existentialism, 24. 
smelled as a great existence which all the people around are under his control. However, wearing the perfume does not grant him the most desired thing he ever wants: a personal identity. When his execution is turned into an orgy, he soon realizes that it is the illusion created by the perfume that brings people into submission, not himself as a person. Even though the perfume has the great power to command everything, it is still not his own smell, which means, it does not belong to him. Under that "olfactory second skin," 64 he still has no odor of himself, no identity, and no existence. With his dream perished, Grenouille commits suicide by pouring the rest of perfume over his body, devoured by vagrants.

His death is of vital importance to express the critique of Enlightenment culture since it announces an Existentialist fight for possessing something that truly belongs to himself. According to Existentialist philosopher Martin Heidegger's notion, death can be seen as "something that cannot be taken away from a particular individual," which has a significant relationship with self-awareness and individual attitude. ${ }^{65}$ Through the possession of his death, Grenouille takes all his creations and doings forever and freezes himself in the history with his uniqueness retained. Ultimately, he stands as a person of distinctive style, an extraordinary talent of olfaction against Enlightenment's repressive dialectic. In this sense, Grenouille's self-destruction becomes a success, and his fighting for identity until the very end of his breath vividly testifies to Existentialist theory that " 'being an individual' in our mass society is an

\footnotetext{
${ }^{64}$ Ed Moffatt, "Grenouille: A Modern Schizophrenic in the Enlightening World of Das Parfum," Forum for Modern Language Studies 37, no.3 (2001): 303.

${ }^{65}$ Carel. Life and Death in Freud and Heidegger, 66-72.
} 
achievement." ${ }^{\prime 66}$ Therefore, the novel and the film pose an intense critique on the Enlightening thoughts of de-characterization, standardization, and suppression of individuality in the early period of capitalist development.

${ }^{66}$ Flynn, Existentialism, 24. 
Netflix’s Parfum (2018): Fragmentation, Trauma, and Self-sufficiency in Contemporary

\section{Neolibaral Capitalism}

First, you get carried off by a wild stream, developing into something almost vulgar, were it not for that sheer love of tenderness, love, and innocence in the background.

--Moritz in Netflix's television series Parfum ${ }^{67}$

In the end of the film Perfume, Grenouille commits suicide and his body is literally torn into pieces. Based on this precondition, Netflix adapts a six-episode television series Parfum that fragments Grenouille's views and traits into a group of characters who lives in contemporary Germany. With six characters specifically representing some part of Grenouille: Elena, Lydia, Moritz, Roman, Butche, and Daniel a.k.a. "The Toothless," Parfum restores Grenouille as a complex existence and implies a fragmentation of identity in contemporary neoliberal capitalist context.

As both a particular economic mode and a "social imaginary" 68 belonging to the broader sense of capitalist system, neoliberal capitalism arose in the 1980s which deems "free markets," individual self-interests, and privatization as its core principles. According to Ryan LaMothe, neoliberal capitalism is defined by four key traits: state and government are not to intervene rather to "free" the market, transactions, and trade; human well-being is best achieved when individual can act out of their "rational" self-interests; "anything and anyone can be

\footnotetext{
${ }^{67}$ Parfum, six episodes, produced by Oliver Berben, Sarah Kirkegaard, featuring Friederike Becht, Natalia Belitski, and Ken Duken, aired November 14, 2018, on Netflix, https://www.netflix.com/title/80200596.

${ }^{68}$ LaMothe, "The Colonizing Realities of Neoliberal Capitalism," 23.
} 
commodified," and "greed can benefit the common good." 69 Acting more on a level of social awareness than mere economical mechanism to affect people's behavior, social practices and moral life, neoliberal capitalism suggests to "shrink" or to limit the influences of government and other public spheres, whereas encouraging people to "self-manage...their welfare, growth, and security that might otherwise be assumed by the state." ${ }^{\prime 70}$ Under such social consciousness, impersonal relations, societal depression and insecurity, as well as suffering, humiliation, and feelings of alienation are brought into everyday life which contributes to the fragmentation of self in people's inner thoughts. ${ }^{71}$

The television series Parfum vividly reflects neoliberal capitalist psyche by reinterpreting the relationships between the notion of smell and the issues of identity. Through adopting a non-linear narrative and a unique character design, Parfum uses flashbacks to break the temporal continuity, divide each character's life story into pieces, and bring the feelings of fragmentation to the audience. Meanwhile, as the characters are traumatized with violence, sufferings and feelings of insecurity, they choose to "rationally" improve their imperfect situations by killing others to make special perfumes that can alter their personal identities. This implies a notion of "self-sufficiency" which individual identity is transformed into a "structure" 72 that can be regularized to effectively satisfy people's selfish goals. In this sense, Parfum creates what I would describe as a cycle of "trauma--self-sufficiency" to address the politics of identity. Also, since the special perfumes are made of body odors that cost others'

69 LaMothe, "The Colonizing Realities of Neoliberal Capitalism," 26.

70 McCarthy, "Reality Television," 25.

71 LaMothe, "The Colonizing Realities of Neoliberal Capitalism," 28-30.

72 McCarthy, "Reality Television," 20. 
lives, smell further implies neoliberal thoughts of objectifying people as commodities: the relationships between people are based on the benefits one can bring about to the others. By manifesting these three characteristics--fragmentation, self-sufficiency, and commodification, Parfum vividly incarnates neoliberal capitalist ideology in its the readdressing of olfactory imagination.

As previously indicated, Grenouille's body is devoured and consumed by a group of vagrants in the original story which he literally becomes an "image of fragmentation"73 with his views divided into multiple perspectives. Thus in Parfum, the audience witness a group of characters that each bears and intensifies some aspects of Grenouille's traits. The character Elena and Lydia represent Grenouille's violence and desires for the sense of existence: they use magic perfumes made by people's body odors to draw attention; at the same time, they are also killers claiming people's lives for their appealing scents like Grenouille did. The character Moritz symbolizes Grenouille's talents in olfaction as he is the one with the most acute sense of smell and works as a master perfumer. Like Grenouille, he has an unusual fascination with creating the "perfect perfume", regarding it as an art. The rest of the characters Roman, "The Toothless," and Butsche embody Grenouille's lack of care, unnoticed existence, and his experience with an unqualified mother and terrible childhood respectively. In the television series, Roman read the book Das Parfum in his teenage years and perceives Grenouille as a monster who craves for love yet can never obtain it, just as he himself is tortured by the fact that he can never gain the love from the woman he feels for. The character Daniel "The Toothless"

73 Moffatt, "Grenouille," 304. 
suffers from mental illness and difficulties in social interactions which make himself feel that he is "nobody" and invisible to the people around. As such, the division of Grenouille's body and mind vividly indicates a fragmented personality, which reflects contemporary neoliberal capitalist language of fragmentation.

Using non-linear storytelling, Parfum's narrative structure resonates with its character design of fragmentation. Beginning with a murder that a woman is killed with her hair, pubic, and auxillary tissue cut, Parfum inlets a lot of flashbacks to connect stories of different characters that took place over a time-span of twenty years. While the investigation of this case unmasks the dark past of the victim's five close friends, police start to re-investigate a twenty-year old case about a missing boy in the same boarding school with them. Later, two more women are murdered in the same pattern which finally uncovers complex stories of killing people for their body odors to make special perfumes. The main plot which revolves around these murders interacts with the sub-stories of each character's past, and by constantly switching back and forth, the flashbacks break the linear cause-effect chain while blurring the past and the present to intensify the audience's feeling of fragmentation. For example, the character Elena's life relates closely to the old murder case happened twenty years ago when a little boy went missing. While we first witness Elena suffer from her husband Roman's violence and disloyalty in the present time, the series soon moves backward in time to reveal her traumatic past experiences of an unhappy childhood without mother's care, an indifferent father paying no attention to her growth; the gang rape from Roman, Butche, and Moritz in her teenage years; and a self-induced abortion that almost killed her, etc. These fragmented scenes scatter in 
different episodes, gradually making the audience understand Elena's desperate desires for love and security. When Roman says "we do it because we like you"74 after the gang rape, Elena regarded Roman as her "boyfriend" and then marries him; when seeing the little boy embraces her mother in the boarding school, she is so fascinated and kills the boy for his scent, making a perfume that attracts the boy's loving mother. These sequences of Elena's past come bit by bit, which intensely break the story's temporal continuity and present her experience as a discontinued iteration without coherent orders. The narrative of the whole series is characterized by such experience of isolation and disconnection where every character's life is constituted of fragmented pieces of events.

While the narrative strategy and character design present neoliberal capitalist characteristic of fragmentation, the characters' fascinations with smells further imply a cultural frame of "trauma--self-sufficiency" that addresses self-identity as a structure and commodity. In her article "Reality Television: A Neoliberal Theater of Suffering," Anna McCarthy contends that trauma constitutes a form of "contemporary common sense" and "neoliberal social reform" dramatized in many television programs to implant neoliberal thoughts of self-sufficiency. ${ }^{75}$ In Parfum, suffering acts as impetus of killing and robbing other scents, helping the characters to modify their identity and take good care of themselves. The whole story is "suffused with tears, rage and insults" $" 76$ as the main characters all have traumatic experiences that put their minds

\footnotetext{
74 Parfum, episode 2, "Skatole," produced by Oliver Berben, Sarah Kirkegaard, featuring Friederike Becht, Natalia Belitski, and Ken Duken, aired November 14, 2018, on Netflix, https://www.netflix.com/title/80200596.

75 McCarthy, "Reality Television," 18. McCarthy lists television programs Extreme Makeover: Home Edition, Judge Judy, Random 1, Intervention, and The Messengers as distinct examples promoting the related neoliberal thoughts.

76 McCarthy, "Reality Television," 19.
} 
and bodies in pain. For instance, the three main female characters--Elena, Simon, and Lydia--all suffer from their sense of imperfect self and choose to use perfumes to beautify themselves. For Elena who grew up without mothering care, killing the little boy and using the perfume made of his odor is a way of "finding herself a mother." Since the perfume, or say the odor of her son reminds the woman of her missing child, the perfumed Elena is adopted by the woman as a substitution of her son. By applying the perfume to her body, Elena modifies her identity, living as the little boy to get the motherly love she desires.

Similarly, the character Lydia and Simon's craving for perfume also rises from their sufferings. Lydia is viewed as a boring, ugly, and joyless woman in man's eyes and an ignored daughter shadowed by her younger sister's optimism and brightness. Her desires for attention and love rise early in her childhood and finally trigger violent behavior of killing three women. By applying the perfume made of these three women's scents, she is making everybody like her, making better of her own existence, and taking good care of herself. The character Simon, a female detective who appears strong and autonomous on the surface, is actually a lonely person who craves for love and company. Growing up without father, Simon sinks into an affair with her married superior who never takes their relationship seriously. She dedicates herself to this affection so deeply regardless of the pain and sorrow, wishing to use perfume to hold on to this man. These varied painful experiences rationalize "a state of need and reason," 77 which further induces individuals' needs of self-sufficiency to navigate themselves out of their traumatized situations.

\footnotetext{
77 McCarthy, "Reality Television," 19.
} 
Also as a "popular language of neoliberal social reform," self-sufficiency means to “apply market-based individualism as a governmental rationale across the institutions and practices of everyday life." ${ }^{78}$ In Parfum, characters' main resort of self-sufficiency is using special perfumes to arm themselves with a "second identity," thereby obtaining the desired things they can never get by being their true self. While they pursue particular kinds of human odor to perfume their body, it is also a process of embodying the identity or multiple identities that the scent represents. In this way, they can live as the "ideal selves" which not only intensifies a fragmentation of personality but also exposes neoliberal thoughts of treating people as commodity.

Ryan LaMothe contends that in contemporary neoliberal capitalist society, "relations and individuals are objectified through commodification" that individual's "uniqueness and value" depend on the person's "direct or indirect relation to profit."79 In this sense, the relationships between people are based not on interpersonal care and love yet on the benefits you can bring about, such as money and reputation. Just as the special perfumes in Parfum are created at the cost of others' lives, the killers treat people as objects of productivity that can bring them interests, meeting their personal needs and satisfying their selfish goals. In Perfume's story universe, perfumes have three chords that play different roles to create special effects to attain a "harmonic affinity." 80 This notion is introduced by Baldini to Grenouille when he works as an apprentice in the novel and the film:

\footnotetext{
78 McCarthy, "Reality Television," 21.

79 LaMothe, "The Colonizing Realities of Neoliberal Capitalism," 28.

80 Perfume: The Story of a Murderer, directed by Tom Tykwer (2006; Germany: Constantin Film; France: Metropolitan Filmexport), DVD, 147 min.
} 
"Each perfume contains three chords: the head, the heart, and the base...The head chord contains the first impression, lasting a few minutes before giving way to the heart chord--the theme of the perfume, lasting several hours. Finally, the base chord, the trail of the perfume, lasting several days." ${ }^{81}$

In the television series Parfum, the three chords are embodied by three women with unique characteristics--a singer Katharina, a prostitute Pearl, and a disabled yet optimistic girl Julia--to play different roles: the wild Katharina as the "head" to elicit man's admiration, the erotic Pearl as the "heart" to arouse sexual desire, and the ingenious Julia as the "base" to evoke love and friendship. The maker of this "perfect" perfume, the character Moritz, interprets its thematic ideas as follows:

"First, you get carried off by a wild stream, developing into something almost vulgar, were it not for that sheer love of tenderness, love, and innocence in the background. $" 82$

Thus, to kill these three women with distinctive characteristics and rob their body odors constitute a process of objectifying them as commodities that can bring benefits, which vividly presents that the relationships between different individuals are based not on "demands of caring for people, except to the extent that care can be commodified and profitable." ${ }^{\prime 3}$ Elena would kill a little boy only for her dream of having a "mother," while Lydia even kills her younger sister

\footnotetext{
${ }^{81}$ Perfume: The Story of a Murderer, directed by Tom Tykwer (2006; Germany: Constantin Film; France: Metropolitan Filmexport), DVD, 147 min.

82 Parfum, episode 6, "Captivation," produced by Oliver Berben, Sarah Kirkegaard, featuring Friederike Becht, Natalia Belitski, and Ken Duken, aired November 14, 2018, on Netflix, https://www.netflix.com/title/80200596.

${ }^{83}$ LaMothe, "The Colonizing Realities of Neoliberal Capitalism," 31.
} 
Julia in order to gain love and attention. In contrast to the novel and the film in which it is a man who kills women and makes them into the perfume, the television series breaks the patriarchal gender boundary by showing that man can also be made into a perfume while women can also be killers. Thus, Parfum's plot shifts the gender masculinity into a more complex level, and the impersonality and indifference of these killings vividly reflect neoliberal capitalism's ideology of commodification on people's behavior and psyche.

In addition to the commodification of others, using perfumes made of people's scents as self-sufficiency further indicates a fragmentation of identity. The special perfumes enable the characters to exist with different identities; as long as their desires are satisfied, the humiliation, alienation, and depression can all be endured. To illustrate, smell gives Elena a second identity: she becomes that little boy and gets herself a loving mother. Yet she is not loved as a person in her own right, but caught by a fragmented and illusive personality which temporarily makes up her traumatic past. When she uses up the perfume, she immediately becomes a "stranger" to that mother. Likewise, the magic perfume meets Lydia and Simon's desires for a while, but they are also trapped by a fragmented self that will finally lead to destruction. Lydia is killed while Simon violates her ethics to hold the perfume secretly. Therefore, the notion of smell functions not only as an instrument manipulating self-sufficiency in Parfum's storyworld, but also criticizes neoliberal capitalist notion of fragmentation that people's identity is transformed into a property that can be regularized, a "psychotic" and false self "preoccupied by one's own desires 
and fantasies." ${ }^{84}$ In this sense, the notion of smell is equipped with new cultural implications in Parfum with a focus on the politics of identity. And the subject of Perfume is thus expanded with neoliberal capitalist notions of fragmentation, self-sufficiency, and commodification.

${ }^{84}$ LaMothe, "The Colonizing Realities of Neoliberal Capitalism," 30. 


\section{Conclusion}

The three texts of Perfume build up a unique story world about olfactory imagination. As an influential work focusing on the notion of smell and self-identity, they shed a light on many aspects of the hidden history of olfaction. From an "animalic" sense to a cultural phenomenon, it took several centuries for people to realize smell's important roles in human society. The three texts analyzed in this thesis highlight the cultural significance of smell, in particular the close relationships between smell and self-identity.

The novel Perfume uses language of "visual symbols" to help the readers understand the protagonist Grenouille's unique world of smell which makes it possible to transform it to a motion picture, a medium that visual perception takes precedence. Telling the same story, the film Perfume successfully uses cinematic techniques of tracking shots, dream sequence, and non-diegetic sound effects, etc. to visualize different scents and portray Genouille's extraordinary olfactory perception. When he uses his nose to acknowledge the world, the audience can visually follow his steps and understand his feelings. Meanwhile, the cultural implication of smell is expressed through Grenouille's life experience: situated in the eighteenth-century Paris when Enlightenment culture dominated the social life, Grenouille's valuing of smell and his robbing of others' scents for his own unique personality pose an intense critique on Enlightenment's suppression of the natural, de-characterization, and the language of standardization. Also processed with scents, Grenouille commits suicide to respond to such social dialectic, an ultimate act of existentialist calling for individuality and fight for his 
uniqueness. Thus, the notion of smell signifies important cultural meanings regarding the issues of identity.

Similarly, from the characters' psychological and behavioral obsessions with scent, the television series Parfum reframes the olfactory imagination within contemporary neoliberal capitalism through its unique character design and non-linear narrative structure. The break of temporal continuity and the separation of Grenouille's characteristics embody the notion of fragmentation under neoliberal capitalism. And by introducing a cultural conception of "trauma--self-suffiency," the television series provides a cause-effect line to elaborate trauma as a common language of neoliberal capitalism and further indicates thoughts of objectifying people as commodities. People's values are judged by the "profit" they can bring about while identities becomes a structure of improving one's welfare and satisfying personal desires. After all, perfume creates only illusions that will eventually disappear, which enables the characters to smell like the desired existence yet never be as the desired existence. Parfum thus reexamines the notion of smell and offers new implications of fragmentation and commodification of self-identity within the broader story of Perfume.

From Süskind's novel to the two media adaptations, Perfume becomes a transmedia property with a key concern of people's struggle of personality under the influence of capitalist development. Henry Jenkins explains the concept of "transmedia storytelling" as "integrating multiple texts to create a narrative so large that it cannot be contained within a single 
medium." 85 Based on Jenkins' observation on narrative, Elizabeth Evans adds two more standards of industrial practice that can define a text as a transmedia property--authorship and temporality ${ }^{86}$ Perfume's three texts share the notion of smell as the central clue of advancing the plots, and they use "close narrative links" $" 87$ to connect and interpret each other in forming a coordinated narrative: the murders of appealing women, the magic power of perfume, and characters' fascination on smell, etc. In addition, the film Perfume (2006) and the television series Parfum (2018) are produced by the same production company--Constantine Film and are released in a specific order to elaborate each other, using intertextual references to help the audience engage and fully understand the interrelated plots. This express institution as an author that ensures the audience a continued viewing experience. Thus, Perfume can be addressed as a "transmedia practice" yet a detailed analysis of it in this term is beyond the scope of this thesis. Nonetheless, the three texts as a transmedia storytelling provide a new avenue to explore further. In addition, the gender issue in relation to smell, olfactory classification, and the modern perfume industry merit an in-depth exploration as well. While smell can be classified by different standards such as flora species, chemical composition, or even music tune, there is always a tendency to connect "desirable women with pleasant fragrances" which categorizes perfumes as feminine objects. ${ }^{88}$ This conception, to a large extent, promotes the development of modern perfume industry and forms a kind of "consumer culture" that links brands of scents

\footnotetext{
${ }^{85}$ Henry Jenkins, Convergence Culture : Where Old and New Media Collide (New York: New York University Press, 2008), 95.

${ }^{86}$ Elizabeth Evans, Transmedia Television: Audiences, New Media, and Daily Life (New York: Routledge, 2011), 28.

${ }^{87}$ Evans, Transmedia Television, 30.

${ }^{88}$ Reinarz, Past Scents, 115-116.
} 
with "beauty, wealth, exoticism, love, and sexual power."89 However, Perfume's stories complicates such understanding by pouring violence and murder into the charming aroma, intimating that perfume might also infer masculinity, patriarchy, and brutality. These venues of studies on smell prove to bring about more insights in the studies of olfactory perception.

In conclusion, Perfume's story universe is of vital importance to us in comprehending the cultural meanings of smell. Centering on people's struggles with the sense of self, it displays how the development of capitalism manipulates and fragments individual identity. Therefore, studying smell as a social and cultural discourse has crucial sense in film and media studies, while it is also helpful to assess its functions in people's everyday life.

${ }^{89}$ Constance Classen, David Howes, and Anthony Synnott, Aroma: The Cultural History of Smell (New York: Routledge, 1994), 187. 


\section{Bibliography}

Butterfield, Bradley. "Enlightenment's Other in Patrick Suskind's 'Das Parfum': Adorno and the Ineffable Utopia of Modern Art.” Comparative Literature Studies 32, no.3 (1995): 401-419.

Carel, Havi. Life and Death in Freud and Heidegger. Amsterdam: Brill Academic Publishers, 2006.

Classen, Constance, David Howes, and Anthony Synnott. Aroma: The Cultural History of Smell. New York: Routledge, 1994.

Corbin, Alain. The Foul and the Fragrant : Odor and the French Social Imagination. Cambridge: Harvard University Press, 1986.

Donahue, Neil H. "Scents and Insensibility: Patrick Süskind's New Historical Critique of 'Die Neue Sensibilität' in Das Parfum (1985).” Modern Language Studies 22, no.3 (1992): 36-43.

Flynn, Thomas R. Existentialism : A Very Short Introduction. Oxford: Oxford University Press, 2006.

Gray, Richard T. "The Dialectic of 'Enscentment': Patrick Süskind's Das Parfum as Critical History of Enlightenment Culture." Publications of the Modern Language Association of America 108, no.3 (1993): 489-505.

Grumley, John. "The Dialectic of Enlightenment Reconsidered." Critical Horizons 20, no.1 (2019): 71-87.

Hassler-Forest, Dan, and Pascal Nicklas. The Politics of Adaptation: Media Convergence and Ideology. New York: Palgrave Macmillan. 2015.

Horkheimer, Max, and Theodor W Adorno. Dialectic of Enlightenment. Translated by John Cumming. New York: Continuum, 1994.

Howell, Amanda. "Breaking Silence, Bearing Witness, and Voicing Defiance: The Resistant Female Voice in the Transmedia Storyworld of The Handmaid's Tale." Continuum 33, no.2 (2019): 216-229.

Hutcheon, Linda, and Siobhan O'Flynn. A Theory of Adaptation. London; New York: Routledge, 2013. 
Jacobson, Manfred R. "Patrick Süskind's Das Parfum: A Postmodern Künstlerroman." German Quarterly 65, no.2 (1992): 201-11.

Jenkins, Henry. Convergence Culture: Where Old and New Media Collide. New York: New York University Press, 2008.

-----." "The revenge of the origami unicorn: Seven principles of transmedia storytelling (well, two actually, five more on friday)." Confessions of an ACA Fan (blog). The Official Weblog of Henry Jenkins, December 12, 2009, http://henryJenkins.org/2009/12/the_revenge_of_the_origamLuni.html.

Evans, Elizabeth. Transmedia Television: Audiences, New Media, and Daily Life. New York: Routledge, 2011.

Kern, Stephen. "Olfactory Ontology and Scented Harmonies: On the History of Smell." Journal of Popular Culture 7, no.4 (1974): 816-24.

LaMothe, Ryan. "The Colonizing Realities of Neoliberal Capitalism." Pastoral Psychology 65, no.1(2016): 23-40.

Major, Wade. "The Slate: Reviews: "Perfume: The Story of a Murderer." Boxoffice, January 2007.

Stamelman, Richard. Perfume : Joy, Obsession, Scandal, Sin ; a Cultural History of Fragrance from 1750 to the Present. New York: Rizzoli, 2006.

McCarthy, Anna. "Reality Television: A Neoliberal Theater of Suffering." Social Text 25, no.4 (2007): 17-41.

Foucault, Michel. Discipline and Punish: The Birth of the Prison. Translated by Alan Sheridan. New York: Vintage Books, a Division of Random House, Inc., 1995.

Milne, Lorna. "Olfaction, Authority, and the Interpretation of History in Salman Rushdie's Midnight's Children, Patrick Suskind's Das Parfum, and Michel Tournier's Le Roi Des Aulnes." Symposium 53, no.1 (1999): 23-36.

Moffatt, Ed. "Grenouille: A Modern Schizophrenic in the Enlightening World of Das Parfum.” Forum for Modern Language Studies 37, no.3 (2001): 298-313.

Parfum, six episodes, produced by Oliver Berben, Sarah Kirkegaard, featuring Friederike Becht, Natalia Belitski, and Ken Duken, aired November 14, 2018, on Netflix, https://www.netflix.com/title/80200596. 
Perfume: The Story of a Murderer folders, Margaret Herrick Library, Academy of Motion Picture Arts and Sciences (AMPAS).

Popova, Yanna B. 2003. “"The Fool Sees with His Nose': Metaphoric Mappings in the Sense of Smell in Patrick Suskind's Perfume.” Language \& Literature 12, no. 2 (2003): 135-152.

Reinarz, Jonathan. Past Scents: Historical Perspectives on Smell. Urbana: University of Illinois Press, 2014.

Rindisbacher, Hans J. "What's This Smell? Shifting Worlds of Olfactory Perception." KulturPoetik 15, no.1 (2015): 70-104.

Ryan, Judith. 1990. "The Problem of Pastiche: Patrick Süskind's Das Parfum." German Quarterly 63 (3-4): 396-403.

Snyder, Mary H. Analyzing Literature to Film Adaptations : A Novelist's Exploration and Guide. New York: Continuum, 2011.

Süskind, Patrick. Perfume. Translated by John E. Woods. New York: Vintage International. 1986.

Perfume: The Story of a Murderer, directed by Tom Tykwer (2006; Germany: Constantin Film; France: Metropolitan Filmexport), DVD, 147 min.

Ventura, Patricia. Neoliberal Culture: Living with American Neoliberalism. New York: Routledge, 2017.

Woolley, Jonathan. "Home Truths: The Importance of the Uncanny for Patrick Süskind's Critique of the Enlightenment in Das Parfum." German life and letters 60, no.2 (2007): 225-242. 